\title{
Exploratory Potential for Gold Placer Deposits in the Coastal Range, BioBío Region, South-Central Chile
}

\author{
Fredy Stange ${ }^{1 *}$, Sonia Helle1, Santiago Collao² \\ ${ }^{1}$ Instituto de Geología Económica Aplicada (GEA), Universidad de Concepción, Concepción, Chile \\ ${ }^{2}$ Departamento Ciencias de la Tierra, Universidad de Concepción, Concepción, Chile \\ Email: ^fstange@udec.cl
}

How to cite this paper: Stange, F., Helle, S. and Collao, S. (2018) Exploratory Potential for Gold Placer Deposits in the Coastal Range, BioBío Region, South-Central Chile. International Journal of Geosciences, 9, 635-657.

https://doi.org/10.4236/ijg.2018.911038

Received: October 8, 2018

Accepted: November 9, 2018

Published: November 12, 2018

Copyright $\odot 2018$ by authors and Scientific Research Publishing Inc. This work is licensed under the Creative Commons Attribution International License (CC BY 4.0).

http://creativecommons.org/licenses/by/4.0/

(c) (i) Open Access

\begin{abstract}
Many gold placers located in the Coastal Range of south-central Chile have been exploited commercially during the past decades; nevertheless and until now, there are not any exploration studies of these placers and their basement. In order to provide an overview of exploratory potential, the stream sediments that are part of several gold placers in the northwest area of the BioBío region are analyzed, which have been registered on the basis of empirical evidence from artisanal mining activities. The overview consists of two goals: 1) determine the presence of auriferous occurrences (stream sediments and basement) and 2) identify potentially favorable areas to find gold placer deposits. Through optical microscopy this study characterized the metallic and non-metallic mineralogy of the basement, along with geochemical analyses of stream sediments and surrounding rocks of the placer deposits. The geochemical results show two sectors with high precious metal contents in sediments (up to $24 \mathrm{ppm}$ of $\mathrm{Au}$ and $8 \mathrm{ppm}$ of $\mathrm{Ag}$ ) and two rocky outcrops with $\mathrm{Au}$ (757 and $41 \mathrm{ppb}$ ). Additionally, there are depressions in the study area that have received large amounts of sediments (reaching up to 170 $\mathrm{m}$-thick), which are favorable places for the accumulation of auriferous sediments from nearby valleys due to the tectonic and structural conditions where they are located. Then, these results show an exploratory potential for gold placers and can be useful to delineate future exploration strategies in the Coastal Range of south-central Chile.
\end{abstract}

\section{Keywords}

Gold, Placer, Exploration, Coastal Range, South-Central Chile 


\section{Introduction}

The National Gold Plan (Plan Aurífero Nacional de Chile) conducted by the Chilean National Mining Corporation (ENAMI) between years 1983-1987 allowed recognizing the gold placers along the country [1], its depositional setting [2] and grouped them into four categories: 1) placers related to Upper Jurassic-Lower Tertiary granitoids, 2) placers related to Paleozoic Metamorphic Basement and/or South Coastal Batholith, 3) placers related to quaternary moraines, and 4) placers located at oceanic beaches. The second category shows the placers distributed between the center and south of the country $\left(\sim 33^{\circ} \mathrm{S}-38^{\circ} \mathrm{S}\right)$ along the Coastal Range (Figure 1).

Evidence of gold occurrences in rocks of the Paleozoic basement in south-central Chile is very scarce; some of them are located near gold placers (e.g., [3]). For instance, a few tens of gold bearing quartz veins with thicknesses between 0.40 and $2 \mathrm{~m}$ hosted in the South Coastal Batholith $\left(32^{\circ} 30^{\prime} \mathrm{S}-38^{\circ} \mathrm{S}\right.$; [4]) are located

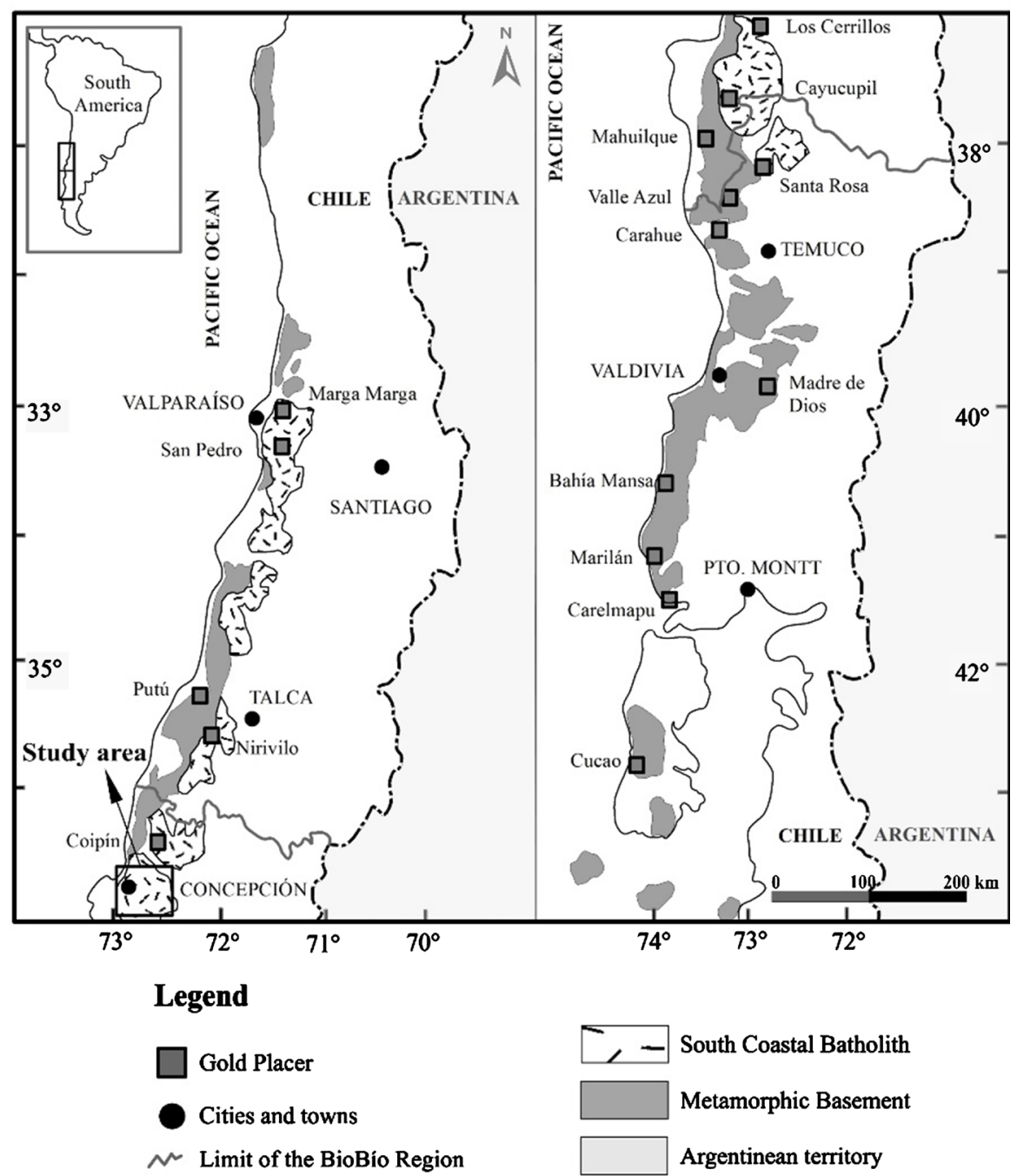

Figure 1. Gold placers in the metamorphic basement and south coastal batholith of Chile (adapted from [2]). 
near the Marga Marga placer (Figure 1) [5]. In addition, areas within this intrusive body display anomalous Au values (up to $8 \mathrm{ppb}$; [6] [7]). Banded Iron Formation (BIF) type deposits hosted in rocks of the Metamorphic Basement [8] [9] have been detected close to the Mahuilque gold placer (Figure 1); these show Au contents (up to $0.36 \mathrm{ppm}$ ) mainly in metacherts [3] and are similar to Au-rich BIF deposits of south-central Africa [10].

Reviews by Pincheira et al. (1991) [1] and Collao et al. (2000) [11] in the BioBío region show a large number of gold placers (120), mainly hosted in modern alluvial and fluvial deposits in the Coastal Range. Some of them (20) have been classified empirically, from observations of local miners, as attractive for exploration $\left(>0.5 \mathrm{~g} / \mathrm{m}^{3} ;[11]\right)$ and spatially related to the Metamorphic Basement and/or South Coastal Batholith [2]. This can be considered as empirical evidence to explore such placers within that geological context.

The gold placers within the Coastal Range of the BioBío region do not have a basic geological description of its outcrops or drill holes (e.g., stratigraphy, composition, shapes, chemical analyzes, etc.) and the reviews just show empirical evidence from artisanal mining activities. Then, as this area is practically unexplored, the study is oriented to provide an overview of exploratory potential for gold placers. This overview comprises two goals: 1) determine the presence of auriferous occurrences (stream sediments and basement) and 2) identify potentially favorable areas to find gold placer deposits. The data to achieve these goals were obtained from geological mapping, petrography of representative rocks, descriptions of eventual mineralizations, and geochemistry of rocks and stream sediments which are part of several gold placers hosted in fluvial deposits (16) located at one sector of the Coastal Range of south-central Chile (Figure 2) and the basement in which they are located.

\section{Geological Setting}

\subsection{Regional Geology}

The oldest rocks in the study area (Figure 2) constitute the Metamorphic Basement of the Coastal Range [12], which are interpreted as an accretionary complex of Carboniferous to late Triassic age [13] [14]. These rocks have been divided into two strips, the Western and Eastern Series [12] [15] [16]. The Western Series consists of mica schists, metabasites, metacherts and serpentinites [15], whereas the Eastern Series is composed of phyllites, slates, schists and gneisses with an increasing metamorphic grade towards the contact with Paleozoic intrusive rocks [17] [18], showing biotite, andalusite and sillimanite zones in the same direction [19] [16].

The intrusive rocks are mainly grouped in the Permo-Carboniferous South Coastal Batholith [20] [18]. Together with this intrusion, during the Permian, the tectonic erosion caused the removal of material from the accretionary complex [19] which led to the loss of a $100 \mathrm{~km}$ portion of land [16]. This batholith is composed of calc-alkaline granitoids [21], ranging from granodiorites and tonalites 


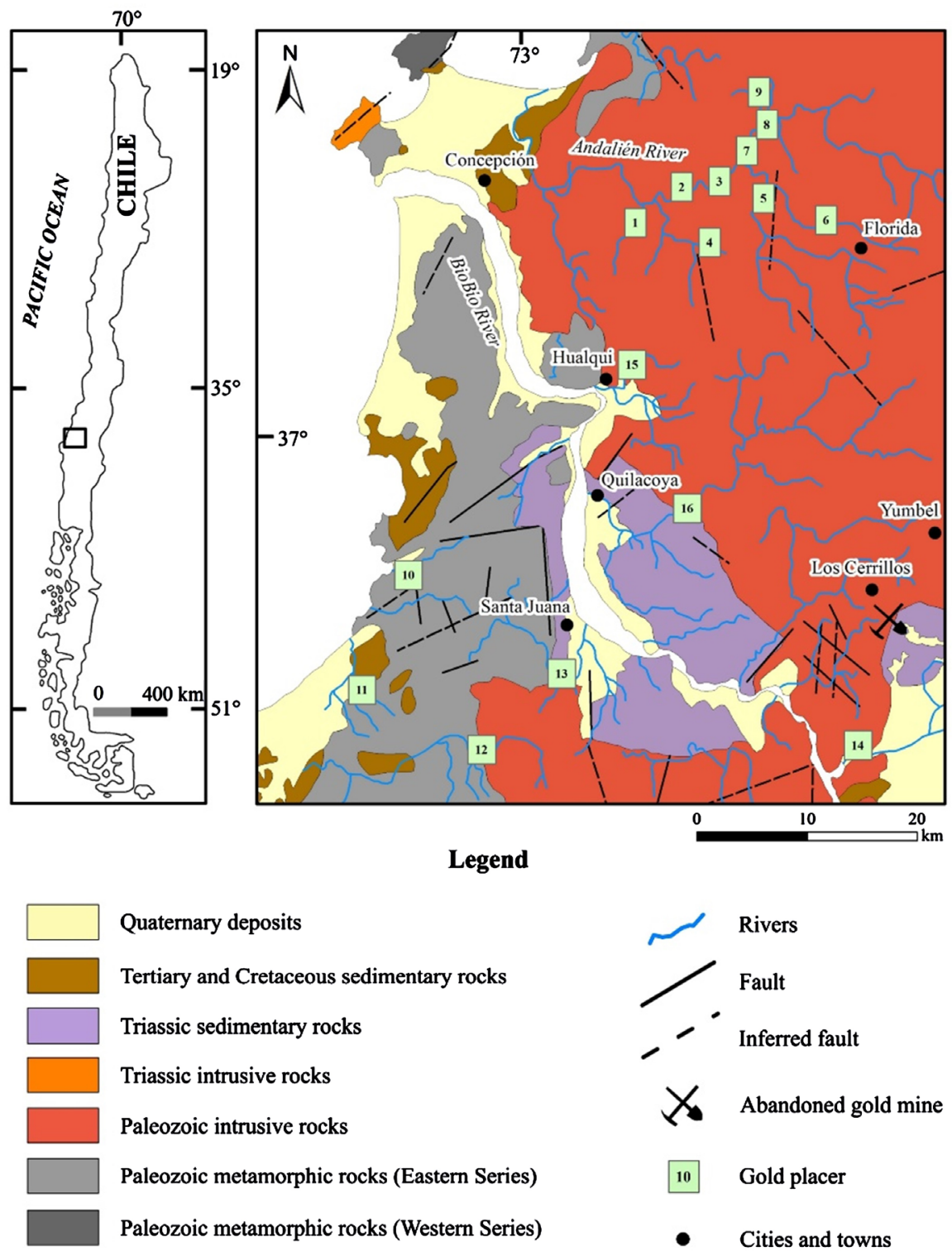

Figure 2. Geological setting (adapted from [11]) and location of gold placers. In addition, rivers and inferred faults (presence of cataclastic material) are shown. (1): Puente 3; (2): Puente 4; (3): Puente 5; (4): Vertiente; (5): Puente 6; (6): Puente 7; (7): Curapalihue; (8): Poñén; (9): Confluencia; (10): Colcura; (11): Laraquete; (12): Río Lías; (13): Santa Juana; (14): Río Laja; (15): Hualqui; (16): Quilacoya.

(center) to granites (margins) [15], and minor amounts of microgranites and pegmatites [4]. In addition, there are small outcrops of Upper Triassic plutonic rocks (Norian; [17] Figure 2), composed mostly of monzogranite (Hualpén Stock; [17]).

From Figure 2, Mesozoic to Cenozoic sedimentary rock sequences overlie the Upper Paleozoic plutonic and metamorphic rocks [22]. The oldest unit, Santa Juana Formation [23], is an Upper Triassic (Carnic; [24]) marine-continental rock sequence, deposited in a NW-SE basin during the initial breakup of Gondwana and the Mesozoic subduction [25]. The main lithologies are arkosic sand- 
stones, shales and claystones, composed of sediments derived from Upper Paleozoic plutonic and metamorphic rocks [24]. Upper Cretaceous (Maastrichtian; [26]) sedimentary marine rocks, represented by the Quiriquina Formation [27], are composed of a basal transgressive conglomerate, fossiliferous sandstones and intercalations of conglomerate [28]. The Cenozoic sedimentary cover comprises marine and continental deposits which are a product of transgression and regression episodes until the Quaternary, within a forearc basin over a continental shelf with epeirogenic movements [22]. These deposits are included in a set of formations known as "Arauco Group", mainly composed of sandstones, claystones and siltstones [29].

The tectonic setting of the south-central Chile margin, characterized by the fast dextral-oblique $\left(\mathrm{N} 77^{\circ} \mathrm{E}\right)$ subduction of the Nazca oceanic plate beneath the South American continent [30], has kept relatively stable since the Pliocene [31]. During the Pliocene-Quaternary, this configuration led to normal faulting with NE preferential orientation, together with uplift and marine regression in the coastal area of south-central Chile [32] which, in turn, allowed the development of the BioBío and Andalién rivers [33].

\subsection{Drainage and Geomorphology}

The studied placers, developed in the BioBío and Andalién basins (Figure 2), are hosted mainly in unconsolidated late Holocene sediments (gravel and sand) [34], which correspond to the current stream sediment deposits, with a maximum thickness of $20 \mathrm{~m}$ [34].

The BioBío river has a drainage basin of $24,000 \mathrm{~km}^{2}$ and a length of $380 \mathrm{~km}$ from the Andes to the coast [35]. The hydric regime is pluvial and nival with flow rates of 700 to $1,300 \mathrm{~m}^{3} / \mathrm{s}$; however, the lower course is completely pluvial with up to $3,000 \mathrm{~m}^{3} / \mathrm{s}$ during winter floods [36]. Furthermore, this river does not have major lakes along its course which causes extreme sediment transport and creates sandbars close to the coast [36].

The Andalién river has a drainage basin located within the Coastal Range [36], with an area of $780 \mathrm{~km}^{2}$ [36]. It is born at the confluence of the Poñen and Curapalihue rivers, has a meandering path and a length of $36 \mathrm{~km}$ [37]. Its hydric regime is pluvial with winter floods and flow rates between $10 \mathrm{~m}^{3} / \mathrm{s}$ in summer and $300 \mathrm{~m}^{3} / \mathrm{s}$ in winter [36].

The most important physiographic unit is the Coastal Range. It is composed of intrusive and metamorphic rocks [38] with average altitudes ranging from 150 to $300 \mathrm{~m}$ a.s.l. [39] and slopes between $15^{\circ}$ and $25^{\circ}$ [38]. Towards the south of the BioBío river, the Coastal Range is progressively raised by ENE-WSW faults in the Metamorphic Basement (Figure 2), from 300 to $650 \mathrm{~m}$ [40].

Morphogenetically, the weather is a relevant factor [38]. The differences in rainfall and temperature averages between winter $\left(\sim 350 \mathrm{~mm}\right.$ and $9^{\circ} \mathrm{C}$; [36]) and summer ( $\sim 50 \mathrm{~mm}$ and $18^{\circ} \mathrm{C}$; [36]) seasons induce erosion processes along the Coastal Range [41]. 


\section{Sampling and Methodology}

Sediment samples were collected along the thalweg of fluvial streams $(\sim 40 \mathrm{~cm}$ below the surface) during the summer months (January, February and March). A total of 132 samples were taken from these streams (each 200 m; Figure 3), with a volume of two liters per sample and particle size smaller than fine gravel $(<2 \mathrm{~mm})$. These were concentrated gravimetrically using a Wilfley vibratory table to obtain the heavy fraction (e.g., [42]), dried in a muffle furnace at $40^{\circ} \mathrm{C}$, homogenized and divided with a riffle sample divider. In parallel, 30 rock chip samples were collected from outcrops (Figure 3 ), each of them equivalent to 5
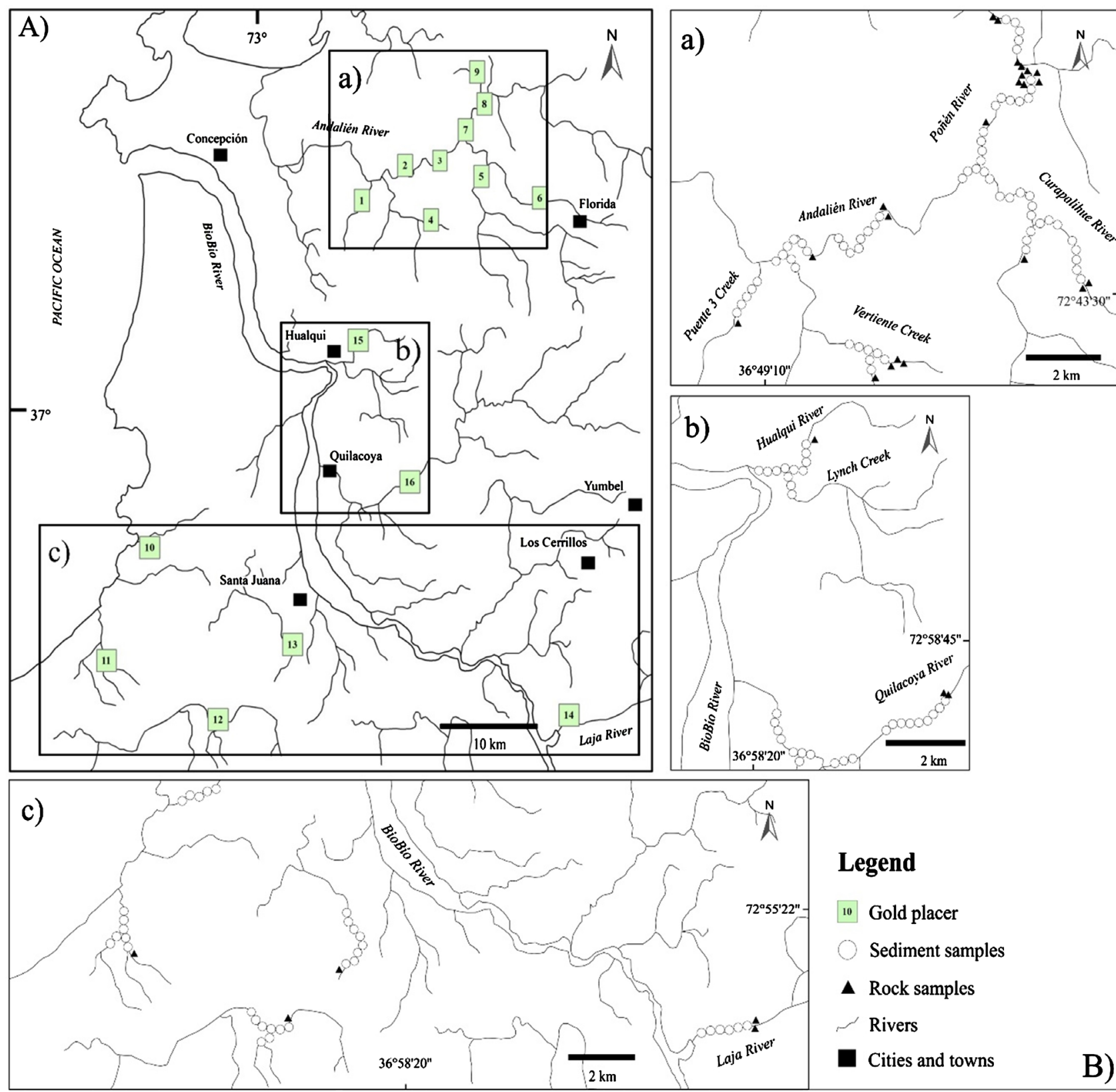

B)

Figure 3. Location of samples in the study area. (A) Selected areas; (a), (b) and (c), related to the studied placers (Figure 2); and (B) Distribution of collected samples. 
$\mathrm{kg}$, representative of $\sim 30 \mathrm{~m}^{2}$, and homogeneous with respect to lithology, meteorization and leaching (e.g., [43] [44]).

The mineralogy of the basement (12 standard transparent-polished sections) was identified by means of an Olympus BX40 optical microscope.

All the procedures mentioned previously were performed at the Departamento Ciencias de la Tierra, Universidad de Concepción, Chile.

Samples for geochemical analysis (sediments and rocks) were pulverized with a tungsten Heiko TI 200 mill and the sediment samples were analyzed at the Instituto de Geología Económica Aplicada (GEA), Universidad de Concepción, Chile. As for the rock samples, they were analyzed at ACME laboratories, Santiago, Chile.

The chemical analysis of the drainage sediments was performed by atomic absorption spectrometry (AAS; Hitachi Z-8100) for the determination of $\mathrm{Cu}, \mathrm{Pb}$, $\mathrm{Zn}, \mathrm{As}, \mathrm{Au}$ and $\mathrm{Ag}$. For $\mathrm{Cu}, \mathrm{Pb}$ and $\mathrm{Zn}$, the samples were dissolved with $\mathrm{HCl}$, followed by a fusion of the insoluble residue with lithium tetraborate. In the case of As, this was extracted by hydride generation (e.g., [45]). Au and Ag were preconcentrated by fire assay (e.g., [46]). The detection limits were: $\mathrm{Cu}, \mathrm{Pb}$ and $\mathrm{Zn}$ : $12 \mathrm{ppm}$; Au: $0.02 \mathrm{ppm}$; As: $0.001 \mathrm{ppm}$; Ag: $0.2 \mathrm{ppm}$. The quality control was performed by means of internal laboratory materials, including standards, duplicates and blanks.

Rock samples were analyzed using induced coupled plasma atomic emission spectrometry (ICP-AES), and in addition, Au was determined by atomic absorption spectrometry. For ICP-AES, a $0.5 \mathrm{~g}$ sub-sample was digested with $3 \mathrm{ml}$ 3-1-2 $\mathrm{HCl}-\mathrm{HNO}_{3}-\mathrm{H}_{2} \mathrm{O}$ leach at $95^{\circ} \mathrm{C}$ for $1 \mathrm{~h}$, and then diluted to $10 \mathrm{ml}$ with water. For Au-AAS, a $10 \mathrm{~g}$ sub-sample was digested with aqua regia at $95^{\circ} \mathrm{C}$ for $1 \mathrm{~h}$, and then diluted to $100 \mathrm{ml}$ with water. The detection limits were: $\mathrm{Au}: 0.5 \mathrm{ppb}$; As: 0.5 ppm; Hg: 0.01 ppm; $\mathrm{Mo}, \mathrm{Cu}, \mathrm{Pb}, \mathrm{Zn}, \mathrm{Ni}, \mathrm{Cd}, \mathrm{Sb}, \mathrm{Bi}$ and $\mathrm{Ag}$ : 0.1 ppm. The quality control was performed by means of internal laboratory materials, including standards, duplicates and blanks.

\section{Results}

\subsection{Field Observations and Petrography}

The principal lithologies in the study area are coarse grained biotite/amphibolebiotite granodiorites and coarse grained biotite granites of the South Coastal Batholith (Figure 2). These rocks are locally cut by quartz veins and aplite dikes, from 1 to $10 \mathrm{~cm}$ thick (Figure 4(a)). Thin sections show that the main minerals are plagioclases (slightly altered to sericite), K-feldspar (microcline slightly altered to clays), quartz, biotite (Figure $4(\mathrm{~b})$ ) and locally epidote. Microdiorite xenoliths, sub-rounded and measuring $5-10 \mathrm{~cm}$ long, are also frequently present. Another common feature is the presence of pegmatite bodies, mainly composed of quartz, K-feldspar (Figure 4(c)) and lesser amounts of muscovite and biotite altered to chlorite, with local occurrence of almandine garnet and tourmaline (dark brown and polychrome). Thin sections of a pegmatite body 

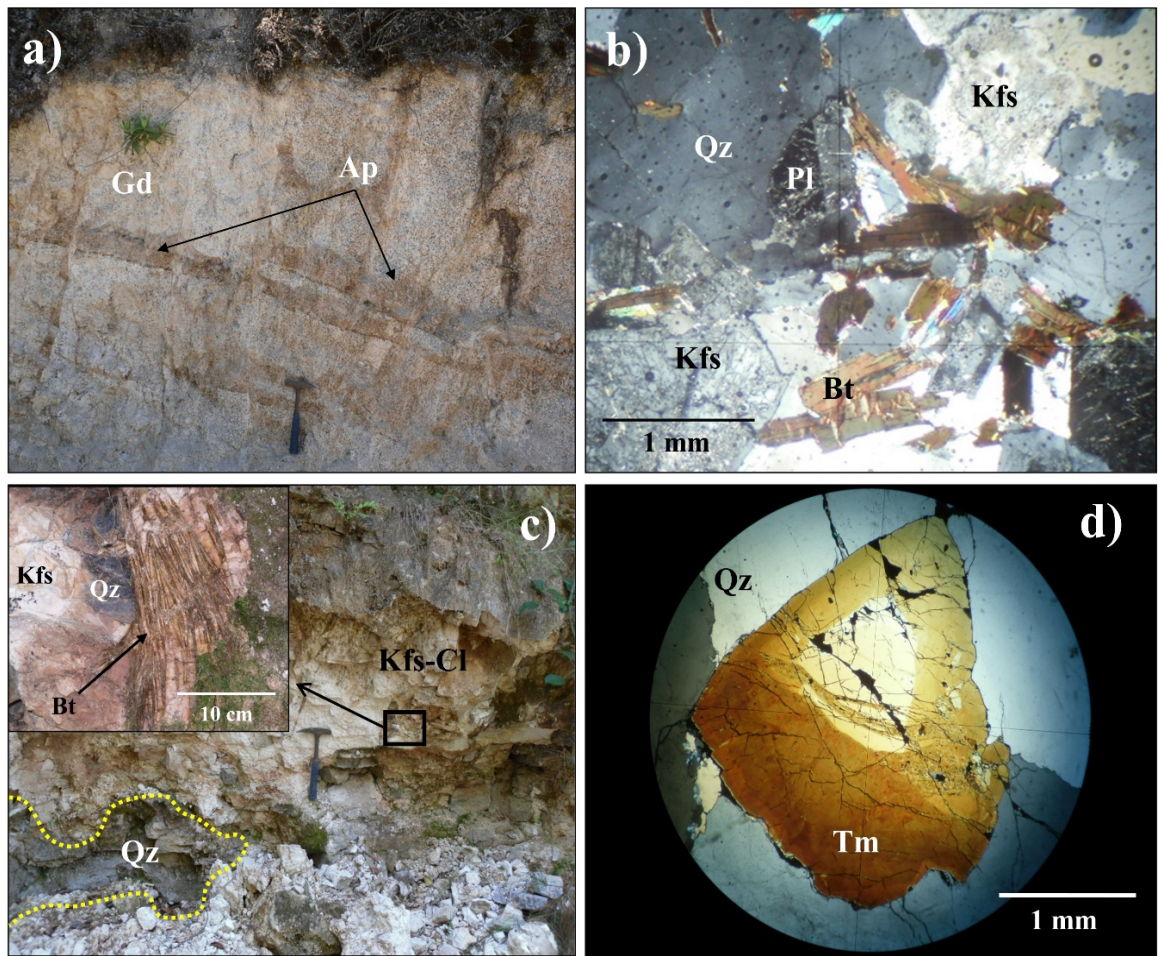

Figure 4. Lithologies in the South Coastal Batholith. (a) Granodiorite outcrop (Gd) cut by aplite dikes (Ap). (b) Thin section of Gd (sample QC-1V; Table 1): quartz (Qz), plagioclase (Pl), K-feldspar (Kfs) and biotite ( $\mathrm{Bt})$, with hypidiomorphic granular texture. (c) Pegmatite near Florida: quartz $(\mathrm{Qz}), \mathrm{K}$-feldspars $(\mathrm{Kfs})$ strongly altered to clays $(\mathrm{Cl})$ and biotite (Bt). (d) Thin section of this body (sample Poñén 1; Table 1): tourmaline (Tm), quartz (Qz). (b) and (d) obtained under optical microscope in transmitted light.

located close to the Poñén placer ("Poñén pegmatite") show quartz and feldspar (plagioclase and microcline) as major components, commonly displaying a graphic intergrowth, with minor amounts of tourmaline (Figure 4(d)). [47] indicates the presence of orthoclase, plagioclase, quartz (smoked and white), micas (biotite and muscovite), besides meta-autunite, chlorite, limonites, clays and traces of rankachite $\left(\mathrm{CaFeV}_{4} \mathrm{~W}_{8} \mathrm{O}_{36} \cdot 12\left(\mathrm{H}_{2} \mathrm{O}\right)\right)$.

In the Quilacoya area, Triassic sedimentary rocks are cut by quartz veins (up to $10 \mathrm{~cm}$ thick) of similar orientation to the stratification, and some orthogonals as part of the same system (Figure 5(a) and Figure 5(b)), with quartz crystals oriented perpendicularly to the walls of each vein (Figure $5(c)$ ). These veins are present at the contact zone between the South Coastal Batholith and the sedimentary rocks (Santa Juana Formation), with strikes varying from $\mathrm{N} 60^{\circ} \mathrm{W}$ to $\mathrm{N} 75^{\circ} \mathrm{W}$ and dips ranging from $60^{\circ} \mathrm{SW}$ to sub-vertical. In thin sections of quartz veins and adjacent wall rock, effects of deformation such as fracturing and recrystallization are observed (Figure 5(d)). The sedimentary rocks around these veins are moderately to strongly argilized, showing alteration halos that reach up to $20 \mathrm{~cm}$, along with limonites (mainly goethitic and minor hematitic; $5 \%$ ) and pyrite boxworks ( $1 \%-2 \%)$, also observed in the quartz veins ( 1\%; Figure 6(a)).

Pyrite and chalcopyrite $(<1 \%)$ and occasionally Fe-Ti oxides (ilmenite) have 


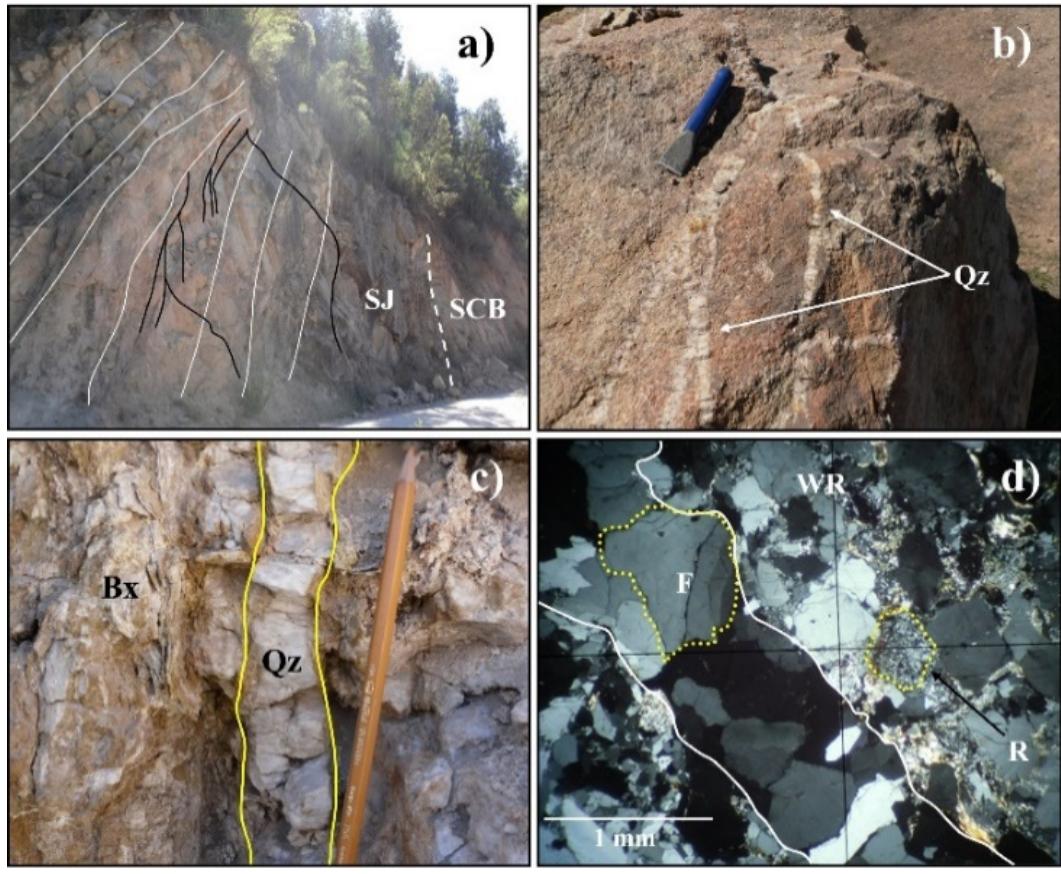

Figure 5. Quartz veins in Quilacoya. (a) Contact zone (dashed line) between sedimentary rocks of the Santa Juana Formation (SJ) and granitoids of the South Coastal Batholith (SCB), where quartz veins (black lines) with similar orientation to the stratification (white lines) and some orthogonals are observed. (b) Detail of polydirectional quartz veins (Qz). (c) Sub-vertical quartz vein (Qz) and brecciated wallrock (Bx). (d) Thin section of these veins (sample Q-1; Table 1): fractured quartz crystals (F) within the vein and recrystallized grains (R) in the wallrock (WR), corresponding to sandstones. (d) obtained under optical microscope in transmitted light.
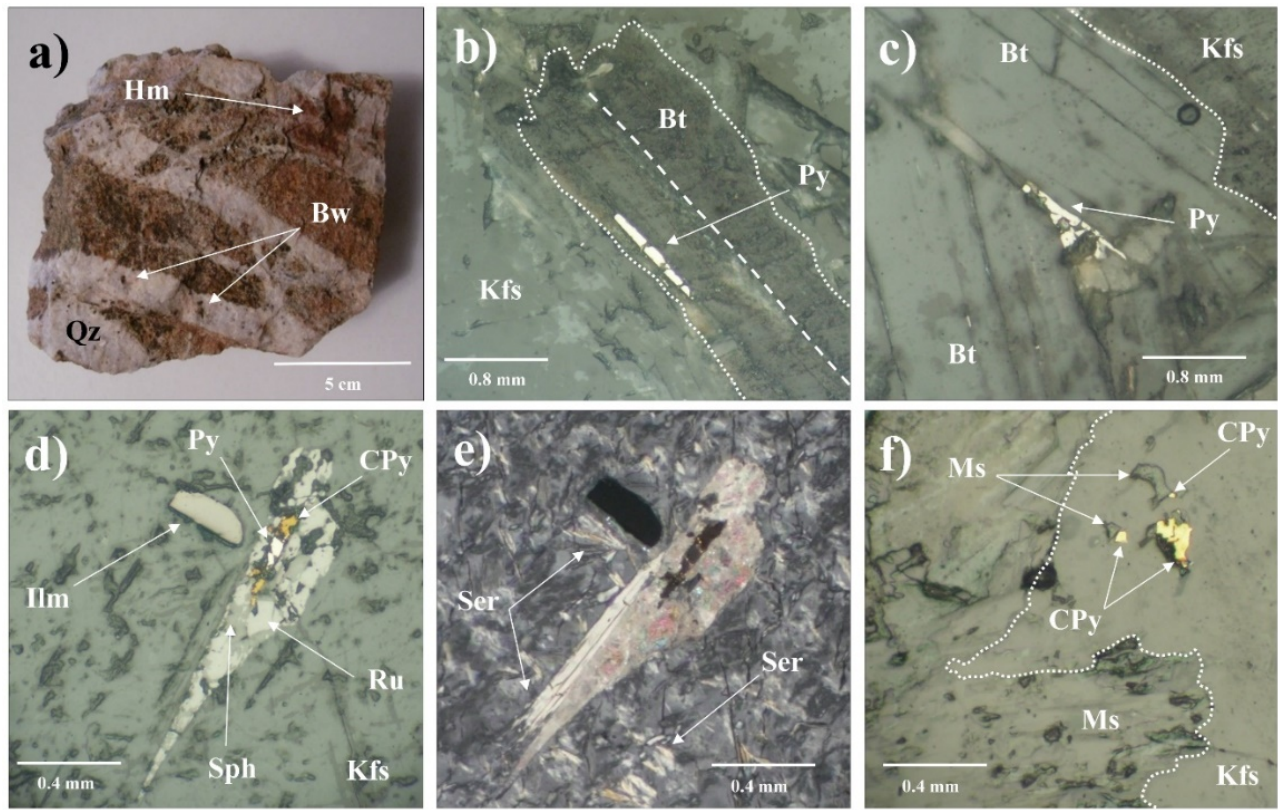

Figure 6. Evidences of metallic mineralization. (a) Sandstone from the Santa Juana Formation with disseminated hematitic limonite $(\mathrm{Hm})$ and pyrite boxworks $(\mathrm{Bw})$ in quartz veins. (b) Pyrite (Py) along cleavage planes (segmented line) in a biotite (Bt) crystal, surrounded by K-feldspar (Kfs). (c) Pyrite (Py) grains between biotite (Bt) crystals in K-feldspar (Kfs). (d) Pyrite (Py) and chalcopyrite (Cpy) associated with rutile (Ru) and sphene (Sph); and (e) Isolated grain of ilmenite (Ilm) in K-feldspar (Kfs) slightly altered to sericite (Ser). (f) Disseminated crystals of chalcopyrite (Cpy) and muscovite (Ms) in K-feldspar (Kfs). (b) and (c) sample Poñén 7 (Table 1); (d)-(f) sample U5-500 (Table 1). (b)-(f) obtained under optical microscope in reflected light. 
been observed only in the Poñén pegmatite. Pyrite occurs as microveinlets, forming a partial fill along cleavages of biotite (Figure 6(b)) and between crystals of this mineral (Figure 6(c)), while ilmenite, rutile, sphene, pyrite and lesser amounts of chalcopyrite occur as anhedral disseminated grains (Figure 6(d)) in K-feldspar slightly altered to sericite (Figure 6(e)). Chalcopyrite also occurs as subhedral disseminated grains, locally in contact with muscovite crystals (Figure 6(f)).

\subsection{Geochemistry of Rocks and Sediments}

Most of the rock chip samples (Figure 3) were obtained from unmineralized unaltered areas in the South Coastal Batholith, including pegmatite bodies (Table 1). In addition, some quartz veins were collected (placer 11 and 16; Table 1 ), but not included in the statistical results. In the case of stream sediment samples, analyzes were conducted on heavy mineral concentrates (Table 2).

Basic statistical results presented in Table 3 for intrusive rocks (granodiorites and granites), pegmatites, quartz veins and sediment concentrates show the number of cases, mean, range, standard deviation and global (world) mean value ranges for intrusive rocks referenced in the same table.

It is not possible to compare the elements found in the sediments with the results collected from rocks given that the former might have different and unknown sources. This is why the following description is made in order to present the metallic content in both cases.

\subsubsection{Rocks}

Molybdenum. Samples of intrusive rocks and pegmatites have mean values $(0.28$ and $0.49 \mathrm{ppm}$, respectively; Table 3 ) lower than the global mean range (1.0 - 1.5 ppm; Table 3). Although, it must be noted that a significant number of samples have Mo contents near to the detection limit $(0.1 \mathrm{ppm})$ or below this. The highest value is observed close to the placer 4 (Vertiente 8: $1.8 \mathrm{ppm}$; Table 1).

Copper. The mean values for samples from intrusive rocks (3.65 ppm; Table 3) and pegmatites (18.85 ppm; Table 3 ) are below the global mean range (30 - 72 ppm; Table 3). The highest values are observed in the Poñén pegmatite (U5-500: > 10,000 ppm; U2X-400: 215 ppm; Table 1).

Lead. Rock samples of the South Coastal Batholith have a mean value (14.43 ppm; Table 3) within the global mean range (4 - 15 ppm; Table 3). Nevertheless, the mean value for pegmatites (106.54 ppm; Table 3 ) is considerably higher than the global mean range, where the highest values are observed close to the placer 8 (U5-500: 802.9 ppm, U2X-400: 590.7 ppm; Table 1).

Zinc. The mean value for samples from the intrusive rocks (28.26 ppm; Table 3 ) is below the global mean range (60 - $94 \mathrm{ppm}$; Table 3), while the samples from pegmatites along the South Coastal Batholith have a mean value considerably higher (666.3 ppm; Table 3) than this range, with the highest value in the Poñén pegmatite (U5-500: 9,522 ppm; Table 1).

Nickel. Most of the samples from the intrusive rocks have low Ni contents 
with a mean value ( $2.37 \mathrm{ppm}$; Table 3 ) below the global mean range (4.5 - 15 ppm; Table 3). In the case of pegmatites, these have a mean value within the global range, with the exception of one sample above this range (U5-500: 119.4 ppm; Table 1).

Table 1. Content of $\mathrm{Mo}, \mathrm{Cu}, \mathrm{Pb}, \mathrm{Zn}, \mathrm{Ni}, \mathrm{As}, \mathrm{Cd}, \mathrm{Sb}, \mathrm{Bi}, \mathrm{Ag}, \mathrm{Au}$ and $\mathrm{Hg}$ in surrounding rocks of the studied placers (Figure 3 ).

\begin{tabular}{|c|c|c|c|c|c|c|c|c|c|c|c|c|c|c|}
\hline Sample & $\mathrm{N}^{\circ}$ & $\mathrm{L}$ & $\begin{array}{c}\text { Mo } \\
\text { (ppm) }\end{array}$ & $\mathrm{Cu}(\mathrm{ppm})$ & $\begin{array}{c}\mathrm{Pb} \\
(\mathrm{ppm})\end{array}$ & $\begin{array}{c}\mathrm{Zn} \\
(\mathrm{ppm})\end{array}$ & $\mathrm{Ni}(\mathrm{ppm})$ & $\begin{array}{c}\text { As } \\
\text { (ppm) }\end{array}$ & $\begin{array}{c}\mathrm{Cd} \\
(\mathrm{ppm})\end{array}$ & $\begin{array}{c}\mathrm{Sb} \\
(\mathrm{ppm})\end{array}$ & $\mathrm{Bi}(\mathrm{ppm})$ & $\begin{array}{c}\mathrm{Ag} \\
(\mathrm{ppm})\end{array}$ & $\begin{array}{c}\mathrm{Au} \\
(\mathrm{ppb})\end{array}$ & $\begin{array}{c}\mathrm{Hg} \\
(\mathrm{ppm})\end{array}$ \\
\hline QC-1C & 1 & (a) & 1 & 7.6 & 4.6 & 49 & 3.3 & 2.3 & $<0.1$ & $<0.1$ & $<0.1$ & $<0.1$ & 7.5 & $<0.01$ \\
\hline CL-1 & 2 & (a) & 0.3 & 0.7 & 15.9 & 7 & 0.6 & 1.9 & $<0.1$ & $<0.1$ & 0.3 & $<0.1$ & 1.6 & 1.39 \\
\hline TN-1 & 3 & (a) & 0.5 & 11.8 & 15.3 & 21 & 1.1 & 6.3 & $<0.1$ & 0.1 & 1.9 & $<0.1$ & $<0.5$ & $<0.01$ \\
\hline P5-1 & 3 & (b) & $<0.1$ & 1 & 9.9 & 6 & 0.4 & 1.5 & $<0.1$ & $<0.1$ & $<0.1$ & $<0.1$ & $<0.5$ & $<0.01$ \\
\hline CC-1 & 4 & (c) & $<0.1$ & 2.6 & 30.1 & 8 & 0.6 & 1.2 & $<0.1$ & $<0.1$ & 0.1 & $<0.1$ & $<0.5$ & $<0.01$ \\
\hline Vertiente 8 & 4 & (b) & 1.8 & 4.9 & 12.5 & 9 & 1.4 & 5.6 & $<0.1$ & 0.2 & $<0.1$ & $<0.1$ & 0.7 & $<0.01$ \\
\hline Vertiente 9 & 4 & (b) & 0.4 & 5.8 & 13.1 & 8 & 1.3 & 1.8 & $<0.1$ & 0.4 & $<0.1$ & $<0.1$ & $<0.5$ & $<0.01$ \\
\hline Vertiente 11 & 4 & (b) & 0.5 & 3.1 & 13.2 & 9 & 0.8 & 2.3 & $<0.1$ & 0.2 & $<0.1$ & $<0.1$ & $<0.5$ & 0.02 \\
\hline P-1 & 5 & (a) & 0.1 & 8.8 & 14.6 & 68 & 6 & 4.1 & $<0.1$ & $<0.1$ & 0.3 & $<0.1$ & 7.8 & 0.04 \\
\hline F-1C & 6 & (b) & 0.4 & 5.9 & 64.5 & 7 & 0.5 & 5.9 & $<0.1$ & $<0.1$ & 0.2 & 0.1 & $<0.5$ & $<0.01$ \\
\hline F-1 & 6 & (b) & 0.1 & 2.2 & 28.6 & 3 & 0.6 & 1.4 & $<0.1$ & $<0.1$ & 0.3 & $<0.1$ & 0.9 & $<0.01$ \\
\hline QC-1V & 7 & (a) & $<0.1$ & 2 & 21.4 & 9 & 0.7 & 3.5 & $<0.1$ & $<0.1$ & 0.2 & $<0.1$ & $<0.5$ & $<0.01$ \\
\hline FP-1 & 8 & (a) & 0.3 & 1 & 4.5 & 12 & 0.8 & 1 & $<0.1$ & $<0.1$ & $<0.1$ & $<0.1$ & 0.5 & $<0.01$ \\
\hline Poñén 1 & 8 & (b) & 0.5 & 3.1 & 4.6 & 92 & 1.3 & 2.5 & $<0.1$ & 0.1 & 0.1 & $<0.1$ & 1.6 & 0.01 \\
\hline Poñén 2 & 8 & (b) & 0.6 & 3.2 & 12.1 & 27 & 1.3 & 4.9 & $<0.1$ & $<0.1$ & 0.1 & $<0.1$ & 1.1 & 0.01 \\
\hline Poñén 5 & 8 & (b) & 0.4 & 3.9 & 4.2 & 47 & 2.5 & 1.8 & $<0.1$ & $<0.1$ & $<0.1$ & $<0.1$ & $<0.5$ & $<0.01$ \\
\hline Poñén 7 & 8 & (b) & 0.7 & 4.4 & 5.5 & 63 & 2.7 & 1.6 & $<0.1$ & $<0.1$ & 0.2 & $<0.1$ & $<0.5$ & $<0.01$ \\
\hline $\mathrm{U} 2 \mathrm{X}-400$ & 8 & (b) & 1 & 215 & 590.7 & 152 & 1 & 424.3 & 0.1 & 10.4 & 5.1 & 3.2 & 756.7 & 1.81 \\
\hline U3-245 & 8 & (b) & 0.4 & 4.4 & 20.5 & 41 & 1.5 & 3.7 & 0.1 & 0.1 & 1.3 & 0.7 & 0.6 & 0.03 \\
\hline U5-500 & 8 & (b) & 0.3 & $>10,000$ & 802.9 & 9,522 & 119.4 & 12.6 & 3.8 & 1.7 & 0.5 & 3.7 & 24.2 & 0.07 \\
\hline RI-1 & 9 & (a) & 0.4 & 3.6 & 20.8 & 86 & 2.8 & 6.3 & $<0.1$ & 0.2 & 0.2 & 0.1 & $<0.5$ & $<0.01$ \\
\hline RI-3 & 9 & (b) & 0.2 & 5.6 & 11.2 & 8 & 0.4 & 1.9 & $<0.1$ & $<0.1$ & 0.1 & $<0.1$ & $<0.5$ & $<0.01$ \\
\hline L-1 & 11 & (d) & 0.4 & 17.4 & 12.2 & 100 & 29.3 & 5.1 & $<0.1$ & $<0.1$ & 0.4 & $<0.1$ & 1 & 0.02 \\
\hline RL-1 & 12 & (b) & 0.1 & 1.4 & 4.7 & $<1$ & 1.2 & 0.7 & $<0.1$ & $<0.1$ & $<0.1$ & $<0.1$ & 1.2 & $<0.01$ \\
\hline CP-1 & 13 & (a) & 0.1 & 0.4 & 0.6 & $<1$ & 0.5 & 0.5 & $<0.1$ & $<0.1$ & $<0.1$ & $<0.1$ & 5.1 & $<0.01$ \\
\hline R-1 & 14 & (a) & 0.2 & 4.1 & 27.2 & 23 & 1.9 & 1.7 & $<0.1$ & $<0.1$ & $<0.1$ & $<0.1$ & 2 & $<0.01$ \\
\hline Y-1 & 14 & (a) & 0.6 & 1.4 & 4.9 & 9 & 8.9 & 1.2 & $<0.1$ & $<0.1$ & $<0.1$ & $<0.1$ & $<0.5$ & $<0.01$ \\
\hline RH-1 & 15 & (a) & 0.1 & 2.3 & 10.5 & 37 & 2 & 5.5 & $<0.1$ & $<0.1$ & 0.2 & $<0.1$ & $<0.5$ & $<0.01$ \\
\hline HQ-1 & 16 & (c) & $<0.1$ & 1.2 & 17.3 & 38 & 1.7 & 5.5 & $<0.1$ & $<0.1$ & 0.1 & $<0.1$ & 2.2 & $<0.01$ \\
\hline Q-1 & 16 & (d) & 0.6 & 2.7 & 8.1 & 5 & 1.5 & 20.9 & $<0.1$ & 0.2 & $<0.1$ & $<0.1$ & 40.9 & 0.09 \\
\hline
\end{tabular}

L: Lithology; (a) Granodiorite, (b) Pegmatite, (c) Granite, (d) Quartz vein. 
Table 2. Content of $\mathrm{Cu}, \mathrm{Pb}, \mathrm{Zn}, \mathrm{As}, \mathrm{Ag}$ and $\mathrm{Au}$ in concentrated sediments of the studied placers (Figure 3).

\begin{tabular}{|c|c|c|c|c|c|c|c|c|}
\hline Sample & $\mathrm{N}^{\circ}$ & Geological setting & $\mathrm{Cu}(\mathrm{ppm})$ & $\mathrm{Pb}(\mathrm{ppm})$ & $\mathrm{Zn}(\mathrm{ppm})$ & As (ppm) & $\mathrm{Ag}(\mathrm{ppm})$ & $\mathrm{Au}(\mathrm{ppm})$ \\
\hline $32-(3 a)$ & 1 & South Coastal Batholith & 45 & 15 & 25 & 0.044 & $<0.2$ & $<0.02$ \\
\hline $24-(3 a)$ & 2 & South Coastal Batholith & 131 & $<12$ & 17 & 0.043 & $<0.2$ & 0.04 \\
\hline $21-(3 a)$ & 3 & South Coastal Batholith & 51 & 18 & 28 & 0.049 & 5.50 & 9.25 \\
\hline $19-(3 a)$ & 3 & South Coastal Batholith & 14 & $<12$ & 16 & 0.035 & $<0.2$ & 0.08 \\
\hline $4-(7 a)$ & 4 & South Coastal Batholith & 23 & $<12$ & 16 & 0.079 & $<0.2$ & 0.04 \\
\hline $16-(3 a)$ & 5 & South Coastal Batholith & 6 & 14 & 11 & 0.034 & $<0.2$ & 0.32 \\
\hline $7-(3 a)$ & 6 & South Coastal Batholith & 6 & $<12$ & 17 & 0.020 & $<0.2$ & 0.05 \\
\hline $9-(3 a)$ & 7 & South Coastal Batholith & 7 & $<12$ & 17 & 0.027 & $<0.2$ & 0.04 \\
\hline $4-(8 a)$ & 8 & South Coastal Batholith & 29 & $<12$ & 16 & 0.053 & $<0.2$ & 0.04 \\
\hline $4-(9 a)$ & 8 & South Coastal Batholith & 22 & $<12$ & 18 & 0.353 & $<0.2$ & 4.91 \\
\hline $12-(1 a)$ & 8 & South Coastal Batholith & 8 & 15 & 52 & 0.090 & 3.7 & 23.86 \\
\hline $4-(14 a)$ & 9 & South Coastal Batholith & 6 & $<12$ & 11 & 0.096 & $<0.2$ & 0.19 \\
\hline $10-(5 a)$ & 10 & Metamorphic Basement & 45 & $<12$ & 35 & 0.279 & $<0.2$ & 0.05 \\
\hline $10-(7 a)$ & 11 & Metamorphic Basement & 13 & $<12$ & 40 & 0.031 & $<0.2$ & $<0.02$ \\
\hline $10-(1 a)$ & 12 & Metamorphic Basement & 28 & $<12$ & 36 & 0.028 & $<0.2$ & 0.06 \\
\hline $10-(3 a)$ & 13 & Metamorphic Basement & 46 & $<12$ & 68 & 0.044 & $<0.2$ & 0.06 \\
\hline $7-(5 a)$ & 14 & South Coastal Batholith & 30 & $<12$ & 35 & 0.018 & $<0.2$ & $<0.02$ \\
\hline $2-(3 a)$ & 15 & South Coastal Batholith & 15 & $<12$ & 23 & 0.045 & $<0.2$ & 0.19 \\
\hline $2-(12 a)$ & 16 & South Coastal Batholith & 69 & $<12$ & 44 & 0.025 & 8.14 & 0.05 \\
\hline $2-(13 a)$ & 16 & South Coastal Batholith & 6 & $<12$ & 9 & 0.022 & $<0.2$ & 0.51 \\
\hline
\end{tabular}

Arsenic. The mean value for samples from the intrusive rocks of the South Coastal Batholith (3.15 ppm; Table 3$)$ is slightly higher than the global mean range (1.5 - $2.0 \mathrm{ppm}$; Table 3). Pegmatites have a mean value (31.5 ppm; Table 3) considerably higher than the range of the global values, with the highest value in the Poñén pegmatite (U2X-400: 424.3 ppm; Table 1).

Bismuth. Samples from intrusive rocks and pegmatites have mean values (0.27 ppm and $0.55 \mathrm{ppm}$, respectively; Table 3 ) higher than the global mean range (0.01 - $0.04 \mathrm{ppm}$; Table 3). The highest value is observed close to the placer 3 (TN-1: 1.9 ppm; Table 1), for intrusive rock samples, and close to the placer 8 (U2X-400: $5.1 \mathrm{ppm}$; Table 1), for samples from pegmatites.

Gold. The mean value for samples from intrusive rocks ( $2.16 \mathrm{ppb}$; Table 3$)$ is below the global mean range (3.2 - $4.5 \mathrm{ppb}$; Table 3); however, local Au contents above this range are observed in the proximities of the placers 1,5 and 13 (QC-1C: 7.5 ppb; P-1: 7.8 ppb and CP-1: 5.1 ppb, respectively; Table 1). The mean value for samples from pegmatites (52.58 ppb; Table 3 ) is considerably higher than the global range, where the highest value can be found in the Poñén pegmatite (U2X-400: $756.7 \mathrm{ppb}$; Table 1). 
Table 3. Geochemical results of rock chip and concentrated sediment samples from the study area.

\begin{tabular}{|c|c|c|c|c|c|}
\hline Element (ppm) & $\mathrm{N}$ & Range (a) & Mean value (b) & Standard Deviation & Global mean values (c) \\
\hline \multicolumn{6}{|c|}{ Intrusive rocks, South Coastal Batholith } \\
\hline Mo & 13 & bd-1 & 0.28 & 0.26 & $1.0-1.5$ \\
\hline $\mathrm{Cu}$ & 13 & $0.4-11.8$ & 3.65 & 3.41 & $30-72$ \\
\hline $\mathrm{Pb}$ & 13 & $0.6-30.1$ & 14.43 & 8.77 & $4-15$ \\
\hline $\mathrm{Zn}$ & 13 & bd-86 & 28.26 & 25.16 & $60-94$ \\
\hline $\mathrm{Ni}$ & 13 & $0.5-8.9$ & 2.37 & 2.39 & $4.5-15$ \\
\hline As & 13 & $0.5-6.3$ & 3.15 & 2.06 & $1.5-2.0$ \\
\hline $\mathrm{Bi}$ & 13 & bd-1.9 & 0.27 & 0.48 & $0.01-0.04$ \\
\hline $\mathrm{Au}(\mathrm{e})$ & 13 & bd-7.8 & 2.16 & 2.68 & $3.2-4.5$ \\
\hline \multicolumn{6}{|c|}{ Pegmatites, South Coastal Batholith } \\
\hline Mo & 15 & bd-1.8 & 0.49 & 0.42 & \\
\hline $\mathrm{Cu}(\mathrm{d})$ & 14 & $1-\mathrm{ad}$ & 18.85 & 54.42 & \\
\hline $\mathrm{Pb}$ & 15 & $4.2-802.9$ & 106.54 & 235.18 & \\
\hline $\mathrm{Zn}$ & 15 & bd- 9,522 & 666.3 & 2367.13 & \\
\hline $\mathrm{Ni}$ & 15 & $0.4-119.4$ & 9.08 & 29.48 & \\
\hline As & 15 & $0.7-424.3$ & 31.5 & 105.02 & \\
\hline $\mathrm{Bi}$ & 15 & bd-5.1 & 0.55 & 1.26 & \\
\hline $\mathrm{Au}(\mathrm{e})$ & 15 & bd-756.7 & 52.58 & 188.28 & \\
\hline \multicolumn{6}{|l|}{ Sediments } \\
\hline $\mathrm{Cu}$ & 20 & $6-131$ & 30 & 29.21 & \\
\hline $\mathrm{Zn}$ & 20 & $9-68$ & 26.7 & 15.11 & \\
\hline As & 20 & $0.018-0.353$ & 0.07 & 0.08 & \\
\hline $\mathrm{Au}$ & 20 & bd-23.86 & 1.98 & 5.47 & \\
\hline
\end{tabular}

(a) bd: below detection limit, ad: above upper detection limit. Elements with $\geq 50 \%$ of values below detection limit are excluded (in Table 1 and Table 2). (b) Mean values were calculated including values below detection limit, considering those as half the detection limit. (c) Global mean value ranges were compiled from the following references: [58] [59] [60] [61]. (d) One analysis above upper detection limit is excluded (sample U5-500: > 10,000 ppm; Table 1). (e) In ppb.

Additionally to the intrusive rocks and pegmatites, high concentrations of $\mathrm{Au}$ and As were locally detected in quartz veins close to the Quilacoya placer (Q-1: 40.9 ppb and 20.9 ppm, respectively; Table 1).

\subsubsection{Sediments}

Copper. Most sediment samples (15; Table 2) have $\mathrm{Cu}$ contents below the mean value (30 ppm; Table 3). Concentrations above the mean value are observed in sediments from the placers $1,2,3,10,13$ and 16 (samples 32-(3a), 24-(3a), 21-(3a), 10-(5a), 10-(3a) and 2-(12a), respectively; Table 2). The highest value is detected in the sample 24-(3a) (131 ppm; Table 2).

Lead. Most samples (16; Table 2) have $\mathrm{Pb}$ contents below the detection limit; therefore, these results are not presented in the Table 3. Concentrations above 
the detection limit are observed in sediments from the placers $1,3,5$ and 8 (samples 32-(3a), 21-(3a), 16-(3a) and 12-(1a), respectively; Table 2). The highest value is detected in the sample 21-(3a) (18 ppm; Table 2).

Zinc. Half of these deposits studied have $\mathrm{Zn}$ contents above the mean value (26.7 ppm; Table 3), which is similar to the copper mean value (Table 3). Concentrations above the mean value are observed in sediments from the placers 3 , $8,10,11,12,13,14$ and 16 (samples 21-(3a), 12-(1a), 10-(5a), 10-(7a), 10-(1a), 10-(3a), 7-(5a) and 2-(12a), respectively; Table 2$)$. The highest value is detected in the sample 10-(3a) (68 ppm; Table 2).

Arsenic. Concentrations of this element are considerably lower than the others (mean value: $0.07 \mathrm{ppm}$; Table 3 ). Concentrations above the mean value are observed in sediments from the placers $4\{4-(7 a)\}, 8\{4-(9 a), 12-(1 \mathrm{a})\}, 9\{4-(14 a)\}$ and $10\{10-(5 a)\}$ (Table 2). The highest value is detected in the sample $4-(9 a)$ (0.353 ppm; Table 2).

Silver. Most sediment samples (17; Table 2) have Ag contents below the detection limit; therefore, these results are not presented in the Table 3. Concentrations above the detection limit are observed in sediments from the placers 3, 8 and 16 (samples 21-(3a), 12-(1a) and 2-(12a), respectively; Table 2). The highest value is detected in the sample 2-(12a) (8.14 ppm; Table 2).

Gold. Most samples have Au contents above the detection limit (17; Table 2), three of them are considerably higher than the mean value (1.98 ppm; Table 3 ) and are observed in the placers $3\{21-(3 a)\}$ and $8\{4-(9 a), 12-(1 a)\}$ (Table 2). The highest value is detected in the sample 12-(1a) (23.86 ppm; Table 2).

\section{Discussion: Potential Areas for Gold Placer Deposits}

In south-central Chile, the most relevant factors that can affect the sediment mobilization dynamics in the drainage basins are: precipitations, water flow, vegetation cover, geomorphology and tectonic environment (e.g., [48] [49] [50]).

Due to the tectonic conditions dating back to the Pliocene, the area where the basins of Andalién and BioBío rivers are located have been subject to an important uplift [32] [31] at average rates of $0.2 \mathrm{~mm} / \mathrm{yr}$ [19], producing disequilibrium profiles [30] and rapid incision along the rivers (rates of $0.43 \mathrm{~mm} / \mathrm{yr}$; [51]); therefore, in these basins a high erosion rate would be expected [52]. In the study area, decadal erosion rates have been estimated from suspended sediments of the BioBio river basin, which were low (0.03 - $0.08 \mathrm{~mm} / \mathrm{yr}$; [52]). However, the data currently available, obtained by surficial sampling (e.g., [53] [54] [52]), does not allow to estimate the bed load and to calculate the ratio between suspended sediment concentration and total sedimentary load; therefore, the erosion rates were underestimated. In the BioBío basin, most erosion processes are focused on high frequency-medium magnitude events (e.g., storms or heavy rainfall), whereas low frequency-high magnitude events (e.g., earthquakes) do not alter the sedimentary flow considerably [54]. It has been observed that the suspended sediments are mobilized during heavy rainfall, always under condi- 
tions of low percentage of green vegetation cover [52], whereas after an earthquake (e.g., the $\mathrm{M}_{\mathrm{w}} 8.8$ Maule earthquake, 27 February 2010) the mobilization of sediments depend mainly on the slope (average of $12^{\circ}$ ) and on connectivity between hillslopes and rivers [52].

The normal water flow in the studied basins can be interrupted by flood events, mainly due to heavy rainfall during the winter months [37], and as a consequence, gold extraction has been made during these months or after heavy rains in past centuries, for example in the Hualqui and Quilacoya placers [11]. These weather conditions probably have produced constant recycling of sediments with detrital gold from the hillslopes to the modern streams (i.e., gold from pre-existing placers; [55] [56]). In addition, although the basement presents discontinuous outcrops, in most of the studied basins this is located a few meters underneath the surface [57], allowing that some gold occurrences would be exposed to the erosion by flooding from watercourses (Figure 7).

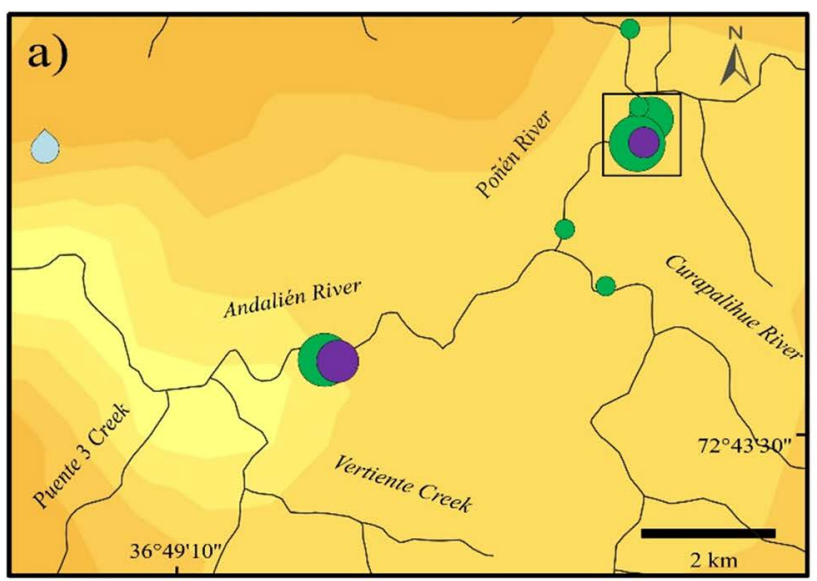

\section{Legend}
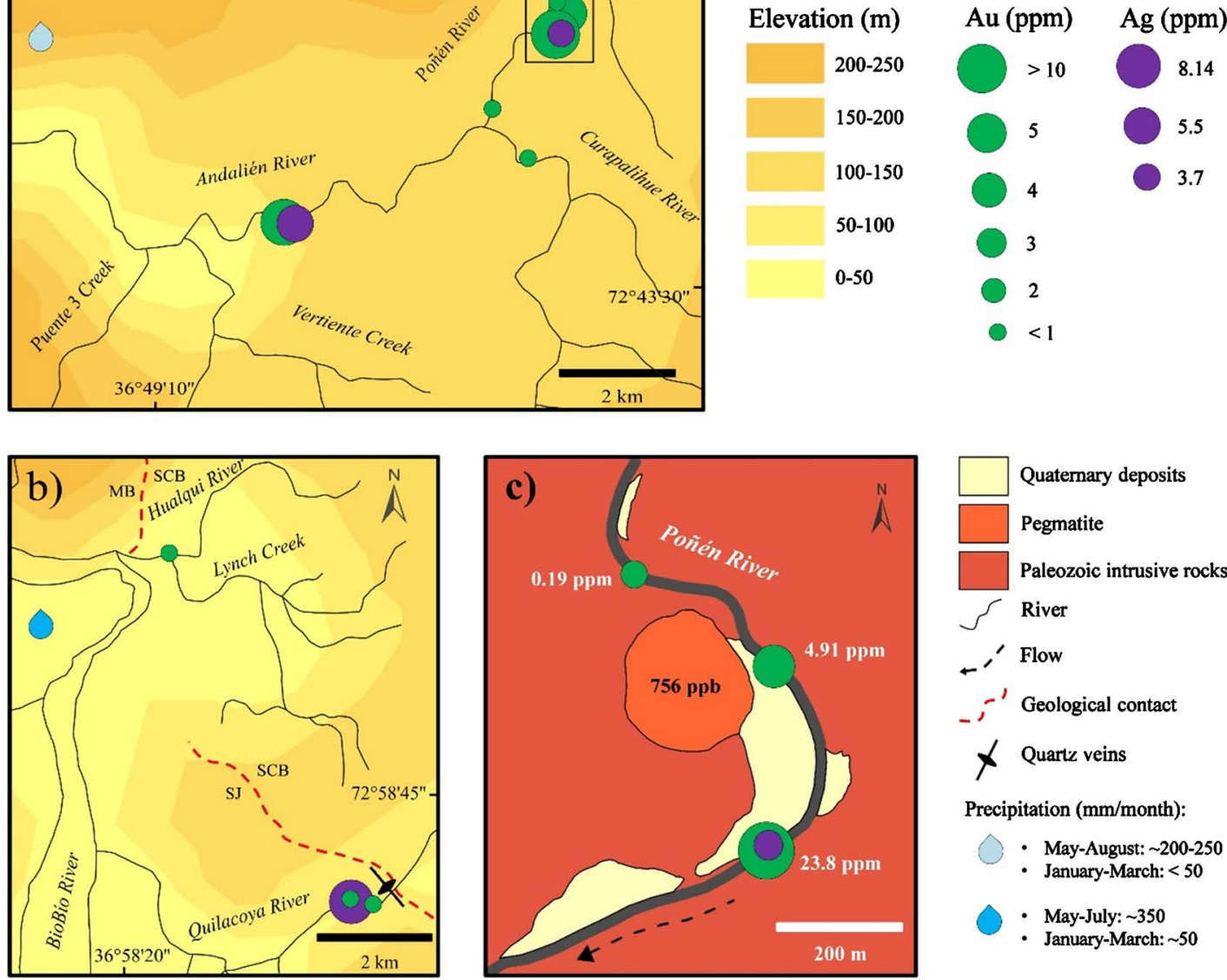

Figure 7. Au and Ag contents from geochemical results. (a) Distribution of Au and Ag in fluvial sediments from the Andalién basin. (b) Relationship between Au and Ag contents in fluvial sediments from the BioBío basin and geological units. (c) Detail of the Poñén placer, showing the relationship between the Poñén pegmatite and sediments with Au and Ag contents (box in (a)). (a) and (b) show the digital elevation model in the background and information on seasonality of the rain. MB: Metamorphic Basement; SCB: South Coastal Batholith; SJ: Santa Juana Formation. 
Geochemical analyses of rock samples reveal that the mean values of pegmatites are higher than those of the intrusive rocks, and in certain cases $(\mathrm{Pb}, \mathrm{Zn}, \mathrm{As}$, $\mathrm{Bi}$ and $\mathrm{Au}$ ) markedly above the global mean range (Table 3 ), such is the case of the Poñén pegmatite (Figure 7(a) and Figure 7(c)). Considering that this body is occasionally eroded by the flooding of the adjacent river, the gold from its outcrop is likely to have fed, at least partially, the nearby placer. Farther south, in the BioBío basin, quartz veins close to the Quilacoya placer show high Au and As contents (Table 1), which makes it likely for this placer deposit to contain gold derived from the erosion of the aforementioned veins by the adjacent river (Figure 7(b)). Then, part of the liberated particles from these occurrences was probably subjected to a short transport.

Given that the uplift, exhumation and erosion processes have affected the Coastal Range of south-central Chile from the Pliocene to the present (e.g., [53]), it is probably that the recycling of gold from pre-existing placer deposits to the modern rivers had provided more auriferous sediments than the occasional erosion of the basement. Some geoforms constitute temporary sedimentary deposits in the studied fluvial systems (e.g., alluvial fans, flood plains, terraces and bars); however, heavy rainfall and persistent uplift in this region of the country would impede the conservation of large accumulations of auriferous sediments.

During the Pliocene and Pleistocene, the Concepción area would have been affected by tectonic phenomena that gave origin to faults with block displacements, which in turn, resulted in a normal fault system with NE preferential orientation (Figure 8) that continues to be active [62] [63]. Such faults limited uplifted blocks that currently form hills between Concepción and Talcahuano and grabens filled with sediments (Figure 9(a) and Figure 9(b)).

These depressions or structural traps (e.g., New Zeland; [65] and their references) have been subject to differential uplift along the faults on its limits, causing erosion of the basement and sediments from hillslopes. Therefore, they not only could have received auriferous sediments transported by the BioBío and Andalién rivers but also gold from possibles occurrences in the basement and pre-existing placer deposits.

The area covered by these depressions (Figure 8) and the thickness of its sediments (up to $170 \mathrm{~m}$; Figure 9(a)), allow to affirm that they were favorable places for the accumulation and conservation of large volumes of sediments [66], which would be potentially auriferous considering that the stream sediments from the BioBío and Andalién basins have detrital gold that could have been accumulated within them, possibly since the Pliocene. Then, these structural traps would be potentially attractive as exploration targets in the study area.

\section{Conclusions}

Through geochemical analyses this research was able to identify the auriferous 

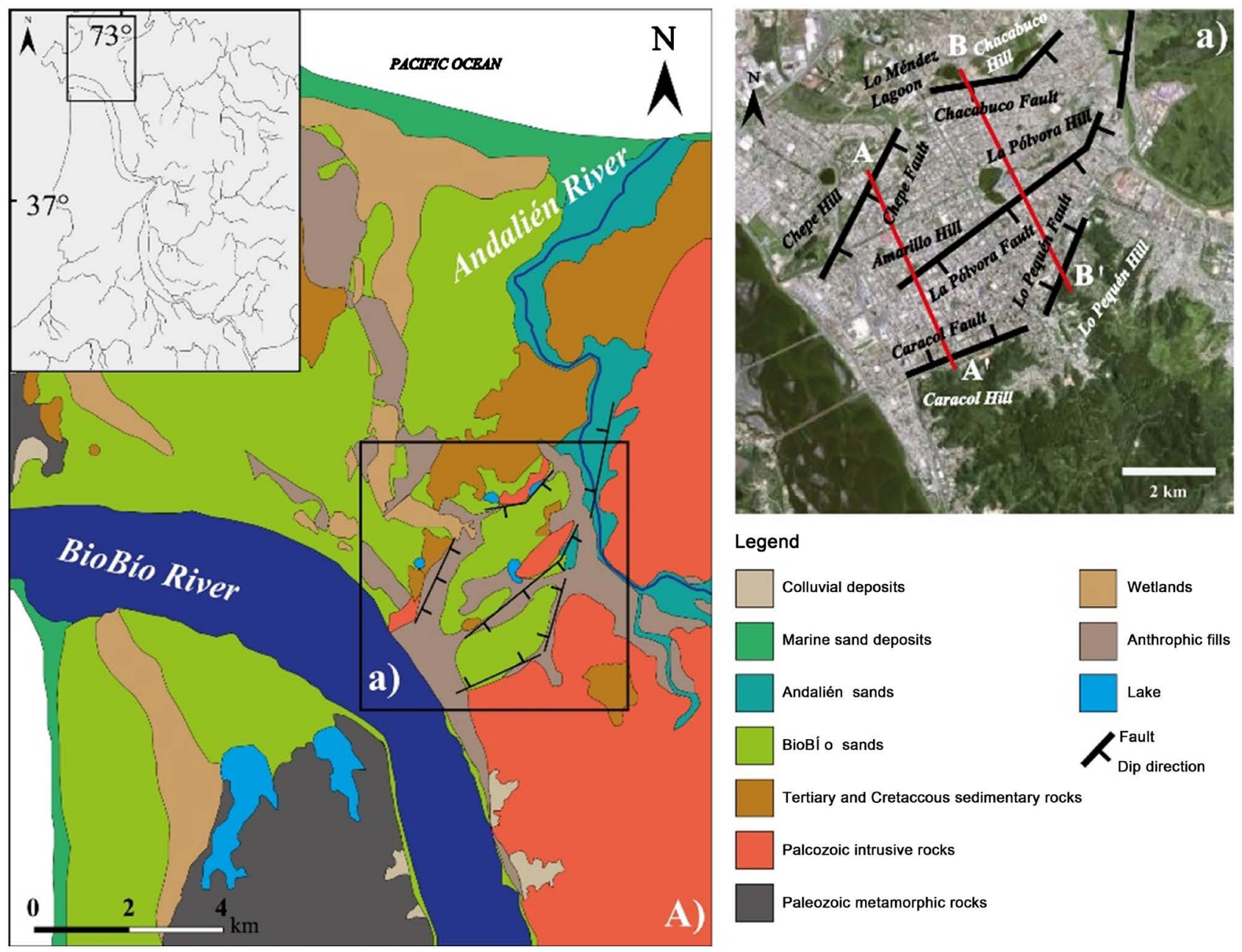

\section{Legend}

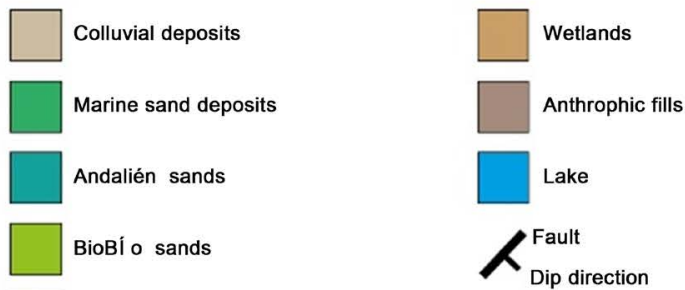

Figure 8. Location of zones potentially favorable for the exploration of auriferous placers. (A) Surface geology of Concepción area (modified from [35] [34] [64]). (a) System of faults and hills that limit the area of interest for the exploration of gold placers. Sections along the lines AA' (Figure 9(a)) and BB' (Figure 9(b)) are also shown.

potential of fluvial placers formed by active sediments in Andalien's basin (Au: Puente 6, Confluencia; Au \pm Ag: Puente 5, Poñén) and Biobío's lower basin (Au: Hualqui; Ag \pm Au: Quilacoya). Moreover, auriferous occurrences are observed in the basement, one of them in the South Coastal Batholith (Poñén pegmatite) and the other one in the contact zone between the latter and sedimentary rocks of the Santa Juana Formation (quartz veins in Quilacoya).

There are zones within the studied basins with placer exploration potential due to their tectonic and structural conditions that favor the accumulation of auriferous sediments from nearby valleys. These are structurally controlled depressions in the area of Concepción which have received large amounts of sediments (reaching up to $170 \mathrm{~m}$-thick). Therefore, the exploration of placers in the Coastal Range of south-central Chile should consider drainage systems that have been subject to tectonic and structural processes which are similar to those registered in the Andalién and BioBío rivers, thus allowing the development of depressions filled with sediments from auriferous valleys. 

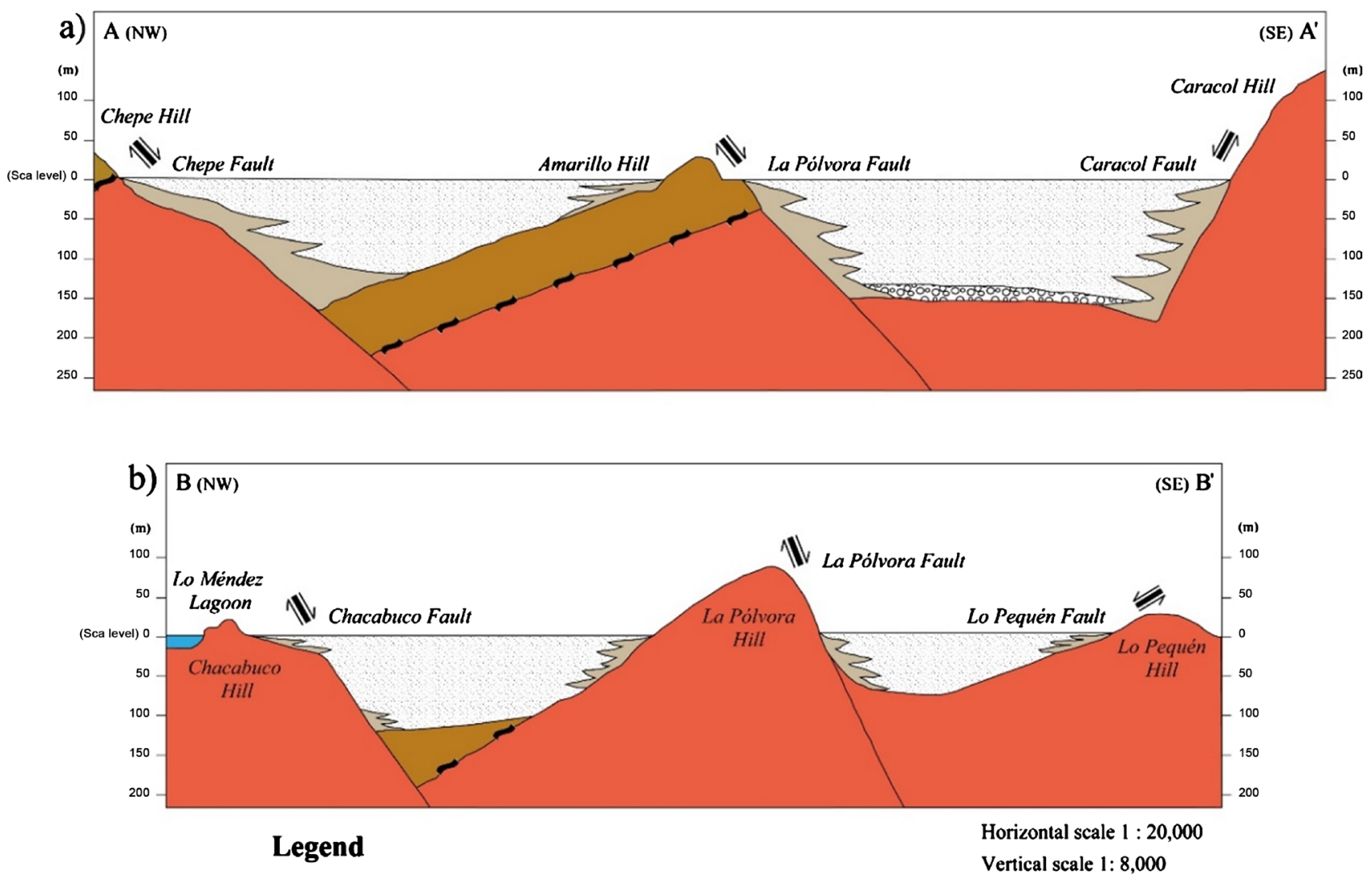

Pliocene/Pleistocene-Holocene

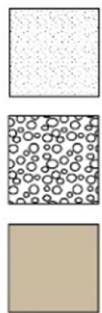

Fluvial deposits

(fine-coarse sand \pm silt)

Gravel

Colluvial deposit (clay-silt \pm sand)

\section{Basement}

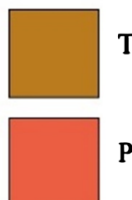

Tertiary and Cretaceous sedimentary rocks

Paleozoic intrusive rocks

Significant unconformities

Figure 9. Geological sections in zones potentially favorable for the exploration of auriferous placers. Sections AA' and BB' show the dimensions (horizontally and vertically) of the structural depressions in the area of Concepción, type of filling, structures and simplified geology of the basement. Both sections were obtained through gravimetric data (modified from [35] [62] [67] [63] [66] [64]).

\section{Acknowledgements}

This study was funded by Universidad de Concepción, DIUC 209025036-1.0 project. We are grateful to Veronica Pineda for her valuable help in the preparation of sediment samples and Gerardo Flores for his logistical assistance during sampling (Universidad de Concepción). We also express our gratitude to Roberto Oyarzun (Universidad Complutense de Madrid, Spain) and one anonymous reviewer for their insightful comments and suggestions.

\section{Conflicts of Interest}

The authors declare no conflicts of interest regarding the publication of this paper. 


\section{References}

[1] Pincheira, M., Jaramillo, E. and Blanco, N. (1991) Evaluación preliminar de los placeres auríferos de la VIII Región, Chile. Universidad de Concepción, Concepción, $65 \mathrm{p}$.

[2] Greiner, G. (1991) Características y distribución de los placeres auríferos de Chile. Symposium Internacional Sur les Gisements Alluviaux d'Or, La Paz, 39-52.

[3] Oyarzún, R. and Helle, S. (1984) Una posible guía de prospección aurífera en rocas del basamento metamórfico de Chile Central-Sur. Minerales, 39, 19-25.

[4] Hervé, F., Godoy, E., Parada, M.A., Ramos, V., Rapela, C., Mpodozis, C. and Davidson, J. (1987) A general view on the Chilean-Argentine Andes, with Emphasis on Their Early History. Circum Pacific Orogenic Belts and the Evolution of the Pacific Ocean Basin, Geodynamics Series, 18, 97-114. https://doi.org/10.1029/GD018p0097

[5] Gonzalez, I. (1991) Sedimentología y mineralogía de placeres auríferos y su relación con yacimientos hidrotermales. Symposium Internacional Sur les Gisements Alluviaux d'Or, La Paz, 61-73.

[6] Ruiz, C. and Peebles, F. (1988) Geología, Distribución y Génesis de los yacimientos metalíferos chilenos. Editorial Universitaria, Santiago, 334 p.

[7] Peebles, F. and Gonzalez, I. (1991) Placeres auríferos del Litoral Central de Chile. Symposium Internacional Sur les Gisements Alluviaux d'Or, La Paz, 53-60.

[8] Collao, S. and Alfaro, G. (1982) Mineralización sulfurada de hierro, cobre y zinc en la Cordillera de la Costa, sur de Chile. Revista Geológica de Chile, 15, 41-47.

[9] Oyarzún, R., Clemmey, H. and Collao, S. (1984) Chemical Characteristics of the Nahuelbuta Mountains Banded iron Formation, Southern-Central Chile. Journal of the Japanese Association of Mineralogists, Petrologists and Economic Geologists, 79, 146-156. https://doi.org/10.2465/ganko1941.79.146

[10] Anhaeusser, C. (1976) The Nature and Distribution of Archean Gold Mineralization in Southern Africa. Minerals Science and Engineering, 8, 47-84.

[11] Collao, S., Alfaro, G., Cecioni, A., González, A. and Quinzio, A. (2000) Evaluación de los Recursos Metálicos de la Región del BioBío, Chile. Universidad de Concepción, Concepción, 207 p.

[12] Aguirre, L., Hervé, F. and Godoy, E. (1972) Distribution of Metamorphic Facies in Chile-An outline. Krystalinikum, 9, 7-19.

[13] Duhart, P., McDonough, M., Muñoz, J., Martin, M. and Villeneuve, M. (2001) El complejo metamórfico Bahía Mansa en la Cordillera de la Costa del centro-sur de Chile (39 $\left.30^{\circ}-42^{\circ} 00^{\prime} \mathrm{S}\right)$ : Geocronología K-Ar, $40 \mathrm{Ar} / 39 \mathrm{Ar}$ y U-Pb e implicancias en la evolución del margen sur-occidental de Gondwana. Revista Geológica de Chile, 28, 179-208. https://doi.org/10.4067/S0716-02082001000200003

[14] Willner, A.P., Glodny, J., Gerya, T.V., Godoy, E. and Massonne, H. (2004) A Counterclockwise PTt-Path in High Pressure-Low Temperature Rocks from the Coastal Cordillera Accretionary Complex of South Central Chile: Constraints for the Earliest Stage of Subduction Mass Flow. Lithos, 73, 283-310. https://doi.org/10.1016/j.lithos.2004.03.002

[15] Hervé, F. (1977) Petrology of the Crystalline Basement of the Nahuelbuta Mountains, South-Central Chile. In: Ishikawa, T. and Aguirre, L., Eds., Comparative Studies on the Geology of the Circum-Pacific Orogenic Belt in Japan and Chile, Japanese Society for the Promotion of Science, London, 1-52.

[16] Willner, A.P. (2005) Pressure-Temperature Evolution of an Upper Paleozoic Paired

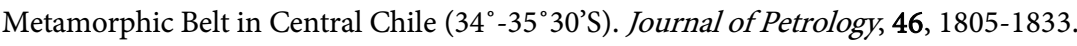


https://doi.org/10.1093/petrology/egi035

[17] Creixell, C., Lucassen, F., Franz, G., Vásquez, P. and Figueroa, O. (2002) Petrology of the Hualpén Stock: Evidence of Late Triassic Epizonal Plutonism at the Western Margin of Gondwana ( $\left.36^{\circ} 45^{\prime} \mathrm{S}, 7^{\circ} 10^{\prime} \mathrm{W}\right)$. International Symposium on Andean Geodynamics, Toulouse, Vol. 5, 167-170.

[18] Hervé, F., Munizaga, F., Parada, M.A., Brook, M., Pankhurst, R.J., Snelling, N.J. and Drake, R. (1988) Granitoids of the Coast Range of Central Chile: Geochronology and Geologic Setting. Journal of South American Earth Sciences, 1, 185-194. https://doi.org/10.1016/0895-9811(88)90036-3

[19] Glodny, J., Echtler, H., Collao, S., Ardiles, M., Burón, P. and Figueroa, O. (2008) Differential Late Paleozoic Active Margin Evolution in South-Central Chile $\left(37^{\circ}-40^{\circ} \mathrm{S}\right)$ - The Lanalhue Fault Zone. Journal of South American Earth Sciences, 26, 397-411. https://doi.org/10.1016/j.jsames.2008.06.001

[20] Hervé, F. (1988) Late Paleozoic Subduction and Accretion in Southern Chile. Episodes, 11, 183-188.

[21] Hervé, F. (1994) The Southern Andes between $39^{\circ}$ and $44^{\circ} \mathrm{S}$ Latitude: The Geological Signature of a Transpressive Tectonic Regime Related to a Magmatic Arc. In: Reutter, K.J., Scheuber, E. and Wigger, P.J., Eds., Tectonics of the Southern Central Andes, Springer Verlag, Berlin, 243-248.

https://doi.org/10.1007/978-3-642-77353-2_17

[22] Frutos, J. and Cisternas, M. (1994) Evolución tectónica de la Cuenca Terciaria de los Andes del Sur de Chile ( $37^{\circ} 30^{\prime}-40^{\circ} 30^{\prime}$ lat. S.). Congreso Geológico Chileno, Concepción, Vol. 7, 32-37.

[23] Ferraris, F. (1981) Avance geológico Hoja Los Ángeles-Angol, Región del Bío-Bío. Instituto de Investigaciones Geológicas, Santiago, Vol. 5, 26 p.

[24] Nielsen, S. (2005) The Triassic Santa Juana Formation at the Lower Biobío River, South-Central Chile. Journal of South American Earth Sciences, 19, 547-562. https://doi.org/10.1016/j.jsames.2005.06.002

[25] Rapela, C.W. and Pankhurst, R.J. (1992) The Granites of Northern Patagonia and the Gastre Fault System in Relation to the Break-Up of Gondwana. Geological Society of London, Special Publications, 68, 209-220. https://doi.org/10.1144/GSL.SP.1992.068.01.13

[26] Salazar, C., Stinnesbeck, W. and Quinzio-Sinn, L.A. (2010) Ammonites from the Maastrichtian (Upper Cretaceous) Quiriquina Formation in Central Chile. Neues Jahrbuch Geologie und Paläontologie Abhandlungen, 257, 181-236. https://doi.org/10.1127/0077-7749/2010/0072

[27] Biró, L. (1982) Revisión y redefinición de los “Estratos de Quiriquina”, Campaniano-Maastrichtiano, en su localidad tipo en la Isla Quiriquina, $36^{\circ} 35^{\prime} \mathrm{S}$, Chile, Sudamérica, con un perfil complementario en Cocholhue. Congreso Geológico Chileno, Concepción, Vol. 3, 29-64.

[28] Pineda, V. (1986) Evolución paleogeográfica de la cuenca sedimentaria Cretácico-Terciaria de Arauco. In: Frutos, J., Oyarzún, R. and Pincheira, M., Eds., Geología y recursos minerales de Chile, Universidad de Concepción, Concepción, 375-390.

[29] Elgueta, S. and Arcos, R. (1993) Geología y modelo de sedimentación de la secuencia Cretácico-Terciaria de la Cuenca de Arauco. Empresa Nacional del Petróleo, Santiago, $32 \mathrm{p}$.

[30] Rehak, K., Strecker, M.R. and Echtler, H.P. (2008) Morphotectonic Segmentation of an Active Forearc, $37^{\circ}-41^{\circ} \mathrm{S}$, Chile. Geomorphology, 94, 98-116.

https://doi.org/10.1016/j.geomorph.2007.05.002 
[31] Melnick, D., Bookhagen, B., Echtler, H. and Strecker, M. (2006) Coastal Deformation and Great Subduction Earthquakes, Isla Santa María, Chile (37 $\left.{ }^{\circ} \mathrm{S}\right)$. Geological Society of America Bulletin, 118, 17.

[32] Quezada, J., Fernández, A., Martínez, C., Pineda, V., Jaque, E. and Isla, F. (2009) Alzamiento holoceno en el litoral del Golfo de Arauco $\left(37^{\circ} \mathrm{S}\right)$ y su relación con los terremotos de subducción. Congreso Geológico Chileno, Santiago, Vol. 12, 4 p.

[33] García, Y. (2004) Aplicación de los métodos círculo de Mohr y programa Reactiva 2.4 en el análisis del stress en las estructuras mayores del área de la ciudad de Concepción, Región del Bío-Bío, Chile. Memoria para optar al Título de Geólogo (Unpublished), Universidad de Concepción, Concepción, 119 p.

[34] Gajardo, A. (1981) Avance geológico Hoja Concepción-Chillán, Región del Bío-Bío. Instituto de Investigaciones Geológicas, Santiago, Vol. 4, 32 p.

[35] Galli, C. (1967) Geología Urbana y suelo de fundación de Concepción y Talcahuano, Chile. Universidad de Concepción, Concepción, 248 p.

[36] Dirección General de Aguas (DGA) (2004) Diagnóstico y clasificación de los cursos de agua según objetivos de calidad, cuenca del rio BioBío, Chile. Ministerio de Obras Públicas, Santiago, $185 \mathrm{p}$.

[37] Niemeyer, H. (1981) Hoyas Hidrográficas de Chile: Octava Región. Dirección General de Aguas (DGA), Centro de Estudios de los Recursos Hídricos, Santiago, 41 p.

[38] Peña, F. (1995) Geomorfología de la ribera norte del rio Biobío en su curso inferior. Limitaciones y potencialidades del área. Revista de Geografía Norte Grande, 22, 27-33.

[39] González, L., Mardones, M., Silva, A. and Campos, E. (1999) Hidrogeoquímica y comportamiento del agua subterránea en la cuenca del río Claro, Región del Biobío, Chile. Revista Geológica de Chile, 26, 145-157. https://doi.org/10.4067/S0716-02081999000200001

[40] Mardones, M. (2005) La Cordillera de la Costa: Caracterización Físico-Ambiental y Regiones Morfoestructurales. In: Smith-Ramírez, C., Armesto, J. and Valdovinos, C., Eds., Historia, Biodiversidad y Ecología de los Bosques Costeros de Chile, Editorial Universitaria, Santiago, 39-59.

[41] Endlicher, W. (1985) Geokologische Untersuchungen zur Landschaftsdegradation im Küstenbergland von Concepción (Chile). Geowissenshaftlichen Fakultat der Universitat Freiburg, Freiburg, 330 p.

[42] Burt, R.O. (1987) Gravity Concentration Methods. In: Yarar, B. and Dogan, Z.M., Eds., Mineral Processing Design, Springer, Berlin, 106-137. https://doi.org/10.1007/978-94-009-3549-5_5

[43] Cruzat, A. (1984) Prospección geoquímica aplicada a yacimientos de oro. Revista Geológica de Chile, 21, 53-75.

[44] Wager, L. and Brown, G. (1960) Collection and Preparation of Materials for Analysis. In: Smales, A. and Wager, L., Eds., Methods in Geochemistry, Interscience, New York, 4-43.

[45] Nakahara, T. (1991) Advances in Atomic Spectroscopy. Spectrochimica Acta Reviews, 2, 95-109.

[46] Fletcher, W.K. and Day, S.J. (1987) Determination of Gold in Heavy-Mineral Concentrates: Fire Assay and Atomic Absorption Spectroscopy (FA-AAS) versus Instrumental Neutro Activation Analysis (INAA). British Columbia Ministry of Energy, Mines and Petroleum Resources, Paper 1988-1, 509-510.

[47] Collao, S., González, L. and Flores, G. (2009) Mineralización de Uranio en Aflora- 
miento Pegmatítico, VIII Región del Bio Bío, Chile. Congreso Geológico Chileno, Santiago, Vol. 12, 4 p.

[48] Antinao, J.L. and Gosse, J. (2008) Large Rockslides in the Southern Central Andes of Chile $\left(32-34.5^{\circ} \mathrm{S}\right)$ : Tectonic Control and Significance for Quaternary Landscape Evolution. Geomorphology, 204, 117-133.

[49] Carretier, S., Pepin, E., Farías, M., Guyot, J.L., Hérail, G., Escobar, F. and Charrier, R. (2009) Relaciones entre tasa de erosión moderna, sismicidad, clima, vegetación y topografía en Chile Central $\left(27^{\circ}-40^{\circ} \mathrm{S}\right)$. Congreso Geológico Chileno, Santiago, Vol. $12,4 \mathrm{p}$.

[50] Tolorza, V., Carretier, S. and Pinto, L. (2012) Descarga de sedimentos fluviales en la Cuenca del Río Biobío: Una aproximación a la erosión integrada de cuenca. Congreso Geológico Chileno, Antofagasta, Vol. 13, 3 p.

[51] Rehak, K., Niedermann, S., Preusser, F., Strecker, M. and Echtler, H. (2010) Late Pleistocene Landscape Evolution in South-Central Chile Constrained by Luminescence and Stable Cosmogenic Nuclide Dating. The Geological Society of America Bulletin, 122, 1235-1247. https://doi.org/10.1130/B26545.1

[52] Tolorza, V. (2015) Magnitud y dinámica de la erosión integrada de cuenca en el rio BioBío. Tesis para optar al Grado de Doctor en Ciencias Mención Geología (Unpublished), Universidad de Chile, $196 \mathrm{p}$.

[53] Carretier, S., Tolorza, V., Rodríguez, M.P., Pepin, E., Aguilar, G., Regard, V., Martinod, J., Riquelme, R., Bonnet, S., Brichau, S., Hérail, G., Pinto, L., Farías, M., Charrier, R. and Guyot, J.L. (2014) Erosion in the Chilean Andes between $27^{\circ} \mathrm{S}$ and $39^{\circ}$ S: Tectonic, Climatic and Geomorphic Control. In: Sepúlveda, S.A., Giambiagi, L.B., Moreiras, S.M., Pinto, L., Tunik, M., Hoke, G.D. and Farías, M., Eds., Geodynamic Processes in the Andes of Central Chile and Argentina, Geological Society, Special Publication, London, 399, 401-418. https://doi.org/10.1144/SP399.16

[54] Tolorza, V., Carretier, S., Andermann, C., Ortega-Culaciati, F., Pinto, L. and Mardones, M. (2014) Contrasting Mountain and Piedmont Dynamics of Sediment Discharge Associated with Groundwater Storage Variation in the Biobío River. Journal of Geophysical Research, 119, 2730-2753. https://doi.org/10.1002/2014JF003105

[55] Levson, V.M. and Giles, T.R. (1991) Stratigraphy and Geologic Setting of Gold Placers in the Cariboo Mining District. British Columbia Ministry of Energy, Mines and Petroleum Resources, Paper 1991-1, 331-344.

[56] James, L.A. (1999) Time and the Persistence of Alluvium: River Engineering, Fluvial Geomorphology, and Mining Sediment in California. Geomorphology, 31, 265-290. https://doi.org/10.1016/S0169-555X(99)00084-7

[57] Dirección General de Aguas (DGA) (2012) Estudio Hidrogeológico Cuenca Biobío, Chile. Ministerio de Obras Públicas, Santiago, 166 p.

[58] Govett, G.J.S. (1983) Rock Geochemistry in Mineral Exploration. In: Handbook of Exploration Geochemistry, Elsevier Science Publishing Company, New York, 461 p.

[59] Lueth, V.W. (1999) Bismuth: Element and Geochemistry. In: Marshall, C.P. and Fairbridge, R.W., Eds., Encyclopedia of Geochemistry, Kluwer Academic Publishers, Berlin, 43-44.

[60] Townley, B., Maksaev, V., Palacios, C., Lahsen, A. and Parada, M.A. (2000) Base and Precious Metals Geochemistry of Rock Units of the Mainland Aysén Region, Chilean Patagonia. Journal of Geochemical Exploration, 68, 21-46. https://doi.org/10.1016/S0375-6742(99)00056-4

[61] Turekian, K.K. and Wedepohl, K.H. (1961) Distribution of the Elements in Some Major Units of the Earth's Crust. Geological Society of America Bulletin, 72, 
175-192. https://doi.org/10.1130/0016-7606(1961)72[175:DOTEIS]2.0.CO;2

[62] Galli, C. (1968) Algunos aspectos de la geología del área de Concepción. Revista del IDIEM, 7, 57-61.

[63] Quezada, J. (1996) Geología urbana y ambiental de la ciudad de Concepción. Memoria para optar al Título de Geólogo (Unpublished), Universidad de Concepción, Concepción, $143 \mathrm{p}$.

[64] Vivallos, J., Ramírez, P. and Fonseca, A. (2010) Microzonificación sísmica de la ciudad de Concepción. Servicio Nacional de Geología y Minería, Carta Geológica de Chile (escala 1:20.000), Serie Geología Ambiental 12, Santiago, 3 mapas.

[65] Kerr, L.C., Craw, D., Norris, R.J., Youngson, J.H. and Wopereis, P. (2000) Structure, Geomorphology, and Gold Concentration in the Nokomai Valley, Southland, New Zealand. New Zealand Journal of Geology and Geophysics, 43, 425-433. https://doi.org/10.1080/00288306.2000.9514899

[66] Ramirez, P. and Vivallos, J. (2009) Microzonificación sísmica de la ciudad de Concepción Chile. Congreso Geológico Chileno, Santiago, Vol. 12, 4 p.

[67] Cecioni, A. and Quezada, J. (1994) Sintesis preliminar de la geología urbana de Concepción. Congreso Geológico Chileno, Concepción, Vol. 7, 595-599. 